\title{
Lean Mentorship: Fitting external support to entrepreneur needs over the startup development
}

\author{
Rafael Barbosa de Aguiara (D), Diego Souza Silva ${ }^{\mathrm{b} *}$ (D), Carla Schwengber ten Caten $^{\mathrm{b,c}}$ (D), \\ Luiz Carlos Pinto Silva Filho ${ }^{\mathrm{c}}$ \\ aPrograma de Pós-graduação em Políticas Públicas, Universidade Federal do Rio Grande do Sul, Porto Alegre, RS, Brasil \\ bDepartamento de Engenharia de Produção e Transportes, Universidade Federal do Rio Grande do Sul, Porto Alegre, RS, Brasil \\ 'Escola de Engenharia, Universidade Federal do Rio Grande do Sul, Porto Alegre, RS, Brasil \\ *diegosilva.ep@gmail.com
}

\begin{abstract}
Paper aims: The present paper aims at exploring aspects of the mentoring process within the practice of technology entrepreneurship, also postulating a new concept, the lean mentorship.

Originality: Although literature examines the effects and nature of mentoring in a variety of contexts, this study pioneers by addressing the mentorship process from the lean startup perspective.

Research method: The study was structured as an exploratory research, drawing on extant literature and a focus group comprised of scholars and practitioners with key roles within an entrepreneurial and innovation ecosystem. The group's discussion was analyzed along with extant literature.

Main findings: The paper further debates and provides insightful perceptions of the key characteristics of the mentorship process, such as the roles of mentors and mentees, the differences and similarities with coaching, and aspects mentorship providers should consider before exposing entrepreneurs.

Implications for theory and practice: The main practical and theoretical contributions of this research are exactly the pioneering nature with regard to the lean startup perspective concerning mentoring. Additionally, conclusions suggests that mentoring providers should engage in experimentations to identify the moment in which entrepreneurs will best benefit from the provision, also mitigating waste of resources, such as time and expenses.
\end{abstract}

Keywords

Technology entrepreneurship. Experimentation. Mentoring. Coaching. Entrepreneurial ecosystem.

How to cite this article: de Aguiar, R. B., Silva, D. S., ten Caten, C. S. \& Silva Filho, L. C. P. (2019). Lean Mentorship: Fitting external support to entrepreneur needs over the startup development. Production, 29, e20190078. https://doi. org/10.1590/0103-6513.20190078.

Received: Jul. 9, 2019; Accepted: Nov. 6, 2019.

\section{Introduction}

There are growing changes in market dynamics and increasing interest in what has been dubbed startups, i.e., technology new ventures operating with resource-restrictions and under higher uncertainties, aiming at finding a repeatable and scalable business model (Blank, 2013; Clarysse \& Bruneel, 2007; Cooper \& Park, 2008; Stayton \& Mangematin, 2018). The startup movement is posing challenges that cross industrial boundaries. In fact, the heavy industry and several large companies (such as General Electric and GoodYear Tire \& Rubber) are turning to these startups and striving to boost agility and entrepreneurial mindset amongst their employees and within their operational settings (Ganguly \& Euchner, 2018; Power, 2014).

Finding successful and efficient ways to stimulate the formation, survival, and growth of startups has been an increasingly important policy issue for most economies, given that companies created to exploit emerging 
technologies are frequently recognized for their high-growth potential and can play a key role in economic activity, job generation and knowledge advancements (Audretsch et al., 2012; 2006). Scientific and technological parks (STPs), alongside with universities, incubators and accelerators, are widely recognized as playing a key role in promoting entrepreneurship, new business development and leaders' training (Caten et al., 2019; International Association of Science Parks and Innovation, 2017; Mian, 1997; Ratinho \& Henriques, 2010; Squicciarini, 2009). Recent studies revealed that startups have greater chances of survival when installed in such environments, reaching discontinuity rates up to 3.45 times lower than ventures located externally to these agents (Arruda et al., 2014; Díez-Vial \& Fernández-Olmos, 2016).

These specialized entities of the innovation ecosystem play an important role in improving the startups' innovative capacity by combining their internal knowledge with outside knowledge, provided by academics or successful and more mature entrepreneurs (Acs et al., 2013). One of the most traditional ways that STPs and incubators mobilize external knowledge is via mentorship (Wu et al., 2019). The exposure to more mature and experienced professionals can be a very powerful way to inspire and motivate young entrepreneurs to focus and mature. The contact with senior mentors help protégés reflect upon, improve or even realign their views about theirs products, skills and business aims, also improving entrepreneurial intentions (Baluku et al., 2019; Brashear-Alejandro et al., 2019).

Adequate and efficient mentorship can therefore play a critical role not only to the consolidation and definition of the focus of young enterprises, but also can be vital to their organizational survival and development, as commented by Löfsten \& Lindelöf $(2001 ; 2005)$. Nevertheless, the effectiveness of mentorship is not always straightforward and it can pose some challenges. For instance, benefits of mentoring may vary according to the degree to which a mentee has a well-defined professional identity (Weinberg, 2019). Additionally, entrepreneurs may not always be prepared to receive mentorship, or be immature to absorb the contributions of some senior experts. Given that mentorship may be a very demanding exercise and that the available time of mentors is a precious and relatively scarce resource, one should strive to make better use of this resource.

To tackle some of the specificities of the startup context, some managerial practices have emerged, like the Lean Startup (LS) methodology. LS has gained momentum in business and academic literature over the past years (De Cock et al., 2019; Mansoori et al., 2019; Yang et al., 2019). Ries (2011) took inspiration in the Japanese lean philosophy to advocate a set of hypothesis-driven practices that aim at assisting technology entrepreneurs in validating business model elements. LS proposes customer-centric activities in the early stages of product development, in order to improve the learning process and avoid wasting scarce resources at hand (Eisenmann et al., 2011).

Offering inefficient or unnecessary mentorship can be a very wasteful and unproductive activity for STPs, incubators and other innovation-driven players. This may be especially important in some intensive technology-based ventures, where development cycles are longer due to material issues, not entrepreneurs' personal advancement and growth. This means that mentorship should be offered at the right time to have better effect and avoid the possibility of being inefficient because the enterprise is not ready to absorb it.

Although extant literature conceptualizes and explores mentoring in a variety of ways and settings, highlighting its importance in startup creation, development and sustainability, there is a dearth of exploration of its misuse as organizational resource (Brashear-Alejandro et al., 2019; Mian, 1997; Ratinho \& Henriques, 2010), also addressing the roles of mentorship and aspects that may share similarities with coaching. Lean philosophy has been introduced to several fields in order to generate and deliver value, also mitigating waste (Hu et al., 2015). In this sense, the present paper aims at furthering debates over the subject by exploring features of the mentorship process, also postulating a new concept: the lean mentorship. This study proposes the organization and provision of mentoring using the lean mindset. The Lean Mentoring advocates that mentoring distributed to startups must be pulled (rather than pushed) from each ventures' needs, maximizing usage, adding value to the startup and avoiding non-absorption of knowledge and information overload.

The idea is that as startups need adequate financial support at different stages of their development cycle, they would also need adequate (suitable and sufficient) mentoring at each stage. Based on this innovative approach, this paper introduces and describes the concept of Lean Mentorship and presents an exploratory study of existing mentoring schemes, mapping their roles in entrepreneurship development while trying to demonstrate that, to make better use of mentorship, a proper management is needed to ascertain the provision of the right knowledge, in adequate amount, at the necessary moment in the startup development cycle. 


\section{Theoretical background}

\subsection{The Lean Startup}

The term Lean Manufacturing was originally coined in a reference to a revolutionary management approach developed by Toyota during post-World War 1l. According to Lean Enterprise Institute (2019), the core idea of lean philosophy is to "maximize customer value while minimizing waste".

Inspired on the fundamental principle of Lean Manufacturing and based on agile management practices, Ries $(2008 ; 2011 ; 2017)$ proposed the Lean Startup (LS) methodology aiming at eliminating waste in product and business development processes in technology-based projects. LS offers a set of practices to improve the way innovation-based business and products are launched, assisting entrepreneurs at validating their hypotheses and focusing on activities that create value for their customers (Frederiksen \& Brem, 2017). The Lean Startup concept arose in an attempt to prevent inefficient investment many young organizations make in services and products that the customer/final user is not interested. Thus, Ries (2011) proposes continuous and frequent experimentation rather than long-term planning.

The Lean Startup methodology is centered in a Build-Measure-Learn (BML) loop. Figure 1 represents the BML loop with examples of practices suitable for each stage ${ }^{1}$. The Build phase is triggered by the development of a minimum viable product (MVP), an initial version of the product with minimum effort that will allow the entrepreneur to assess market response, testing critical assumptions and getting feedbacks as quickly as possible (Lenarduzzi et al., 2016; Ries, 2011). During BML loop, the entrepreneur must evaluate whether the product development efforts are being effective or not.

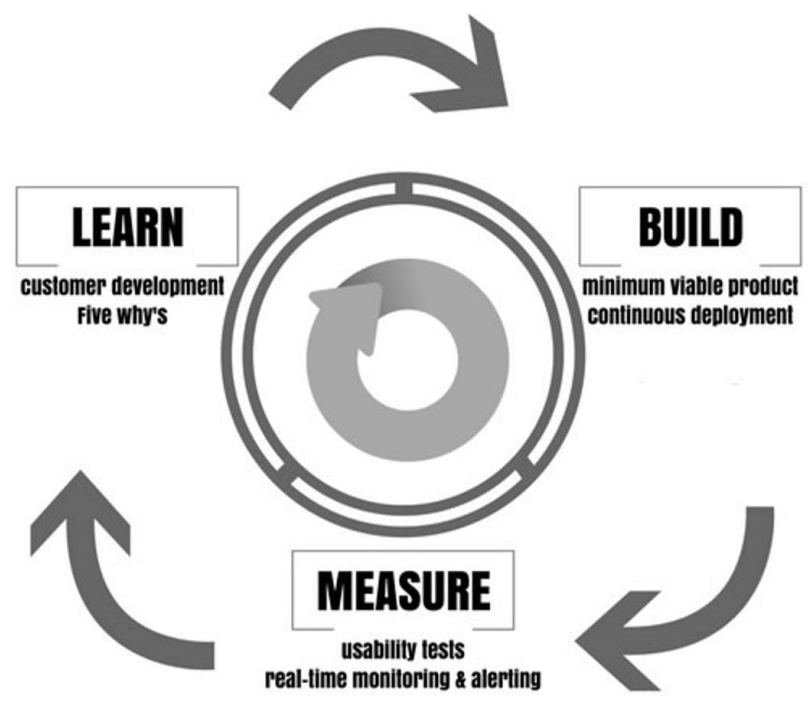

Figure 1. Build-Measure-Learn loop. Adapted from Ries (2011).

By the end of the BML loop, the entrepreneur must decide whether to persevere on his/her original strategy or to "pivot." A pivot is an adjustment in one or more business model elements, changing small features of the product or conducting more significant modifications in the whole project (Bajwa et al., 2017; Ries, 2011).

The Lean Startup is a hypothesis-driven methodology that maximizes information gathered and mitigates uncertainty inherent to technology entrepreneurship (Eisenmann et al., 2011). The methodology advocates development of innovation-based products and business by means of quick and continuous interactions with customers since early stages of the venture, providing the entrepreneur validated learning experience, which will support the following challenges of the organization.

\footnotetext{
Not all practices in Figure 1 are mandatory for the BML loop. They were listed as to better exemplify the stages. For instance, the "Five Why's" is a managerial technique in which one can explore cause-and-effect relationships underlying a problem by asking "why" consecutively, until reaching a root-cause. We suggest its use in the Learning stage, as it promotes a better understanding of a situation.
} 


\subsection{The role of knowledge in entrepreneurship}

Globalization and digitalization have contributed to deep transformations in economy and market for the past few decades. One of the main changes lies in comparative advantage, such as observed within OECD countries, becoming increasingly based on new knowledge, rather than based on traditional inputs of production (Audretsch \& Thurik, 2001). Despite its importance, knowledge is inherently different from production inputs as it provides an asymmetric potential value across economic agents (Arrow, 1962a,b; Audretsch \& Keilbach, 2008).

The role knowledge plays in firms creation has been acknowledged by the diffusion of the Knowledge Spillover Theory of Entrepreneurship (Agarwal et al., 2007; Audretsch \& Keilbach, 2008; Audretsch \& Lehmann, 2005). The theory states that underexploited or uncommercialized knowledge created by firms and research organizations spills over to other economic agents, generating new organizations (Acs et al., 2013). There is empirical evidence supporting the theory, revealing that industries with greater investments in knowledge also presented higher startup rates, whereas industries with less investment in new knowledge presented lower startup rates (Audretsch \& Lehmann, 2005).

The knowledge spillover theory establishes that the spillover of knowledge is one mechanism for identifying opportunities and implementing them by starting a new business. The source of such knowledge and ideas generated may be an established corporation or a research laboratory within a university. Thus, an entrepreneur deciding to locate its new firm nearby a university can also benefit from university spillovers (Audretsch \& Lehmann, 2005).

Studies have evidenced that contexts rich in knowledge generate higher rates of entrepreneurial opportunities (Acs et al., 2013; Audretsch \& Lehmann, 2005). Hence, knowledge is a key underpinning for competitiveness and must be continuously pursued by entrepreneurs and provided by economic agents in order to foster entrepreneurial behavior.

\subsection{Entrepreneurial Mentoring}

Organizational dynamics have been transformed in the face of current career and rapid-change environments. Large companies are turning to startups, downsizing, outsourcing and also shifting employment paradigms, appreciating employment mobility rather than stability, focusing on flexibility and adaptability to bolster innovation (Ensher et al., 2000; Euchner, 2016). According to the Brazilian Micro and Small Business Support Agency, in recent years, 8.9 million SMEs in Brazil represented 27\% of the national GDP, and provided more than half of Brazilian formal jobs (Serviço de Apoio as Micros Empresas, 2014; 2015). These figures highlight the importance of entrepreneurship in the Brazilian scenario, also suggesting opportunities for would-be entrepreneurs.

However, entrepreneurs are not always well prepared, which leads to the major cause of bankruptcy in nascent businesses: the lack of experience and skills, also observed in poor business vision and the inability to find a growth niche for their venture (Gurdon \& Samsom, 2010; Hansford et al., 2002; St-Jean \& Audet, 2013). On the other hand, the development of entrepreneurial capabilities during first years of the business is determinant to its survival (Gartner et al., 1998). In order to increase their chances of succeeding, entrepreneurs must quickly develop fundamental competencies. Thus, an increasing number of entrepreneurs seek the assistance of a mentor (St-Jean \& Audet, 2013), since mentoring is considered an effective way to transfer entrepreneurial knowledge, skills, and attributes (Moore \& Wang, 2017; St-Jean \& Mathieu, 2015), which has great influence over entrepreneurial success (Waters et al., 2002).

There is not a unique definition of mentoring (El Hallam \& ST-Jean, 2016; Hansford et al., 2002; Moore \& Wang, 2017; St-Jean \& Audet, 2013). Herein, the authors of the present paper adopted the concept stated by St-Jean \& Mathieu (2015, p. 2): “mentoring is a support relationship between a novice entrepreneur (where lack of experience is key), named mentee, and an experienced businessperson, named mentor, where the latter helps the former to develop as a person. Trust and perceived similarity are needed in order to build a strong relationship in the dyad."

Studies on the topic have linked mentoring to a wide range of benefits and obstacles for both mentees and mentors (Brashear-Alejandro et al., 2019; Hansford et al., 2002; Weinberg, 2019). Previous researches reinforce the relevance of entrepreneurial mentoring to entrepreneurship and the entrepreneurs development arguing that it can assume a critical role to the business' sustainability (St-Jean, 2012; St-Jean \& Audet, 2013; Waters et al., 2002). Additionally, both mentees' learning ability and absorptive capacity were revealed to be fundamental elements for successful mentoring (Szulanski, 1996). 


\section{Methodology}

This study adopted an exploratory and qualitative descriptive research. The paper comprehends a discussion of mentorship provision drawn from the lean philosophy aiming at maximizing knowledge absorption and reducing economic and value perception waste.

The study also presents a literature review with the purpose of identifying key practices related to knowledge management in STPs and areas of innovation (incubators, accelerators), and investigate research opportunities, as well as be conducive to future researches on the field (Merriam \& Tisdell, 2009; Yin, 2011). Furthermore, it discusses research gaps and reflections on how Lean Mentorship could be applied in practice, based on data gathered from a focus group, organized to present the issue to scholars and practitioners from a Brazilian innovation ecosystem.

Based on the literature, the authors structured a questionnaire (Appendix A) and, following similar recent publications (e.g. Caten et al., 2019; Monticelli et al., 2018), this study adopts the focus group technique with participants from Porto Alegre, Brazil. Porto Alegre is the capital of Rio Grande do Sul State, Southern Brazil, and is ranked seventh in a recent report revealing the best 32 Brazilian cities for entrepreneurs (Endeavor, 2015), also housing STPs relevant on both regional and national contexts with research centers of global-leading-companies like SAP, HP and Huawei. The present study adopted the focus group technique to further explore debates drawing on extant literature and shed light on unexpected tangential issues, as it provides a better understanding of "how people feel or think about an issue, idea, product, or service" (Krueger \& Casey, 2014, p. 26). Also, focus groups enable "discovery of the complexity of actors' views and their involvement in their stories, revealing similarities and differences, agreements and contradictions (Monticelli et al., 2018, p. 7). Following the suggestions of Krueger \& Casey (2014), participants were selected considering communal characteristics relevant for the topic development. Thus, the focus group was comprised by seven scholars and innovation managers. The participants' names will be kept classified and herein they will be identified as "P1", "P2", "P3" ... "P7". Table 1 reveals the members' profiles and backgrounds.

Table 1. Focus group members.

\begin{tabular}{cccc}
\hline PARTICIPANT & EDUCATION & EXPERIENCE & MENTOR/MENTEE \\
\hline P1 & Undergraduate in Physics & 18 years & Mentor \\
P2 & PhD. in Energy & 18 years & Mentor (1 year) and Mentee (4 years) \\
P3 & Publicity Specialist & 30 years & Mentor \\
P4 & Electrical Engineer & 30 years & Mentor \\
P5 & Computer Scientist & 25 years & Mentor \\
P6 & MSc. in Business & 25 years & Mentor \\
P7 & MBA in Strategy Management & 19 years & Mentor/Coaching and Consultant \\
\hline
\end{tabular}

The focus group debate lasted two hours, and was recorded, transcribed, indexed and analyzed, as suggested by Bloor et al. (2001). The authors employed a reasoning of recursive and cyclical interpretative-oriented content analysis explicitly stating the research concerns and selecting relevant speech marks for further analysis (Auerbach \& Silverstein, 2003). Drawing on the guidelines by Saunders et al. (2016), the study employed inductive coding to group similar findings regarding mentorship in technology entrepreneurship. Hence, we reduced and analyzed data following the pattern coding exercise (c.f. Miles \& Huberman, 1994), which allowed the authors to group summaries (found within the transcription) into smaller number of constructs, indicating the following nodes: "mentoring versus coaching", "roles of mentorship process", "mentorship starting point", and "additional findings." All data were continuously compared to extant literature (Strauss \& Corbin, 2008) as to provide timely contributions for theory and practice. The main topics will be discussed in the following section.

\section{Analysis and discussions}

During the focus group, three main topics emerged (mentoring versus coaching, key roles of mentorship, and ideal mentorship moment). Each one generated a subtopic which will be forward discussed.

\subsection{Mentoring versus Coaching}

Fostering entrepreneurial mindsets and offering training greatly contribute to entrepreneurship activities and the subsequent economic growth (Klofsten \& Öberg, 2012). The promotion of entrepreneurship can be done in a variety of ways; one of them is to make use of training processes such as coaching or mentoring. 
Mentors provide young entrepreneurs with sponsorship, coaching, visibility and preparation for enhancement, offering role modeling, counseling and friendship, assisting in the development of professional identity and competence (Brashear-Alejandro et al., 2019; Kram \& 1sabella, 1985). On the other hand, according to the International Coach Federation (2018), coaching relates to the maximization of personal and professional potential by means of partnering with clients in thought-provoking and creative processes.

During the discussion about mentoring and coaching definitions, P7 classified mentoring into two groups: customer-demand mentoring and modeling mentoring. In the former, "customer brings the demand to improve an indicator, the initial step is to make a diagnosis, find alternatives that are feasible and take action". Next, modeling mentoring consists in "shaping people's behavior based on the behavior of someone who is reference doing a great job", whereas coaching brings deeper reflection on various aspects of life, assuming that everyone has strengths and for some reason people don't develop it by themselves. In addition, P7 asserted that "coaching applies scientifically-proven tools and brings encouragement to new experiences and consequently new behaviors. It is a complete process, affecting emotional issues and behavior, also generating mindset change."

In the literature, the definitions of coaching are not very different from the ones assigned to mentoring, and in literature, many definitions become intertwined. Thus, one may find difficulty in characterizing the limits between the processes of mentoring and coaching (Silva, 2010).

When it comes to the differences between mentoring and coaching, P4 stated that "mentors use their experience to make entrepreneurs grow as professionals and people, without a systematic methodology." According to P4, mentors must know about the mentees' business and use previous experience to assist them, whereas coaches are qualified professionals in tools and techniques, but not necessarily having previous business experience.

When questioned about the boundaries between the terms mentoring and coaching, P5 asserted that "it is not unusual for a single person to hold both roles of mentor and coach." According to P5, the reach of mentors' role goes beyond the business development; the mentor will also assist the entrepreneur in personal development and behavioral transformation. P4, giving a practical example, said that an accelerators' business has to develop persons. "If the accelerator doesn't develop the entrepreneur, the venture will be doomed to fail. So a good mentor is someone who can broaden the entrepreneurs' horizons and assist them to take [good] decisions." Hence, mentors are not supposed to just deliver solutions.

\subsection{Key roles of mentorship}

Evidence from literature shows that mentors perform a number of functions within a mentoring relationship (Kram \& 1sabella, 1985; Schockett \& Haring-Hidore, 1985). According to Schockett \& Haring-Hidore (1985), mentors execute eight different functions: as role model, motivator, counselor, friend/colleague, educator, consultant, sponsor and protector. Kram \& lsabella (1985) highlighted nine mentoring functions: sponsorship, coaching, exposure and visibility, protection, challenging work assignments, acceptance and confirmation, counseling, role modeling and friendship.

When questioned about the mentor's role, the discussion was consistent with literature. P6 asserted that "mentor is the one who assumes the image of a sponsor, guiding and joining the entrepreneur for a time being. [...] He is almost a friend" while P2 stated that "mentors motivate through their experience and make the mentees evolve." Lastly, P7 said that "mentors must have technical and emotional qualifications to lead entrepreneurs out of their comfort zone, provoking them to take actions and achieve the expected results."

During the discussion, other characteristics concerning mentoring emerged, such as: mentor experience, openness to same-level conversation, humbleness, being a good listener and provocative, empathy, and trust. These characteristics can reduce the main challenges of mentoring process that include the issues of poor quality of mentors, arbitrary supervision and unavailability of incentive mechanisms (Ting et al., 2017).

\section{3. ldeal mentorship moment}

The survival of a new venture lies in the development of key skills and competencies, which may be improved by means of properly designed support. However, the needs of new entrepreneurs do not appear to be adequately considered in the design of their support programs (St-Jean \& Audet, 2012). Many mentees complain that the training they receive is not tailored to their needs, suggesting that a more personalized learning process may be appropriate (Morrison \& Bergin-Seers, 2002).

When questioned about offering mentorship at the right time and amount, P1 and P3 believe mentors are far from being great, but despite the issues concerning the improvement of mentorship process, they are doing 
the best they can. According to P4, the main challenge of innovation players like accelerators and incubators is to achieve the full potential of the mentors capabilities, so as to take the most from them and enhance the entrepreneurs skills. P6, discussing about the startup context, stated "there are some tools we use a lot; one of them is the experimentation." The main purpose of experimenting is to test hypotheses and analyze whether they do or do not work. Hence, some agents of innovation ecosystems can incorporate this mindset and realize the best timing to implement mentorship by means of experimentation. In addition to experimentation, P7 declared that mentees' openness to behavioral change may also influence the result.

The mentors discussions in the focus group were in line with mentees' perceptions brought by Morrison \& Bergin-Seers (2002). Finally, P6 stated that mentors should be submitted to training programs, in which they would improve mentorship processes, developing more systematized and standardized methodologies.

\section{Further discussions}

Two additional subjects emerged during the focus group discussion and deserve further analysis. The first regards mentors rewards, and the second concerns the measurement of results from mentoring processes.

Financial rewards remain the most criticized subject in mentoring. Some researchers found rewards motivating for mentoring while others believe they are insignificant (Mishra et al., 2016). Self-motivated mentors do not seek rewards out of mentoring, but some prefer rewards as the source of financial benefits (Cholakova \& Clarysse, 2015). Prior investigations have also argued that mentoring is a philanthropic activity that requires passion (Kram \& 1sabella, 1985; Lester et al., 2008). Thus, the preference for financial rewards has largely been suppressed and remained unexplored and undervalued in the literature (Mishra et al., 2016).

The focus group was asked on the main encouraging factors for being mentors. According to P1, the value lies in the mentors' own learning process. P4 stated four main reasons: (1) learning, (2) networking, (3) the will of becoming angel investors, and (4) a sense of fulfillment by giving back to society. Although P1 declared not having money involved in this process, P4 affirmed eventually having equity payment. Lastly, P3 presented two groups of mentors: "the ones who are mentors for a living, charging for the service; and the ones doing for philanthropic reasons."

Some studies in current literature address concerns regarding evaluation of the entrepreneurial mentoring effect, but most of these studies are ad hoc qualitative description (Ensher et al., 2000), whereas others use financial performance indicators, such as sales growth and market share (Kurtulmuş \& Warner, 2015), and non-financial indicators, like employee satisfaction (Antoncic \& Hisrich, 2003). In practice, measuring the mentoring effect quantitatively, veritably and objectively is difficult (Ting et al., 2017).

When it comes to difficulty to measure entrepreneurial mentoring, P4 declared having no idea how to measure it. Additionally, P1 pointed to a dearth of academic and practical studies, providing guidelines on this matter. Both P1 and P6 reported using personal feedbacks from mentees to analyze whether the mentoring results were either positive or negative. According to P6, overall, the mentor succeeds by providing the entrepreneur new key references that widen the entrepreneur's business perspective.

Even though the participants exposed difficulty regarding the measurement of entrepreneurial mentoring process, its benefits have shown to be noticeable. As stated by $\mathrm{P} 1$, he observed a problem and he first started mentoring, "only those ventures who succeeded were able to evolve, and there were very few new entrants [entrepreneurs], making the ecosystem restricted and weak." According to him, the ecosystem naturally matured as new entrepreneurs emerged, also increasing the demand (and offer) of mentors, and giving dynamism to the entrepreneurial ecosystem. As P1 concluded, "the ecosystem evolves as more people get engaged. Previous mentees become mentors and everyone grows."

\section{Concluding remarks and venues for future agenda}

One of the major challenges of professionals involved in entrepreneurial development is to create means to guide individuals to outline a career and life project compatible with their competencies, interests and values (Silva, 2010). In this scenario, mentoring processes are presented by companies and professionals as an alternative to overcome such challenges. However, few studies seek to evaluate the actual effectiveness of these processes (Morrison \& Bergin-Seers, 2002; St-Jean \& Audet, 2012), and there is an evident blurriness concerning the definitions of such processes by both academic and professionals, as also observed in the focus group discussion presented. 
This paper contributes to the literature by conducting an exploratory research and collecting perceptions over the startup mentoring process. However, like in any qualitative research, this study is not free of limitations. We must consider that a major limitation regards focusing one single context of a Brazilian entrepreneurial ecosystem. Further research should explore different settings and investigate the suitability of lean mentorship across several contexts and fields.

The findings are of more than academic interest. Practitioners, leaders and innovation managers behind innovation-based businesses must be aware of the new training practices such as mentoring and coaching. As main contributions, the study identified difficulties in the definition of the best moment for a startup to receive a mentoring process, as well as a dearth of guidelines to assist mentors in measuring results. Additionally, respondents agreed there are improvement opportunities in the mentoring process. Future research could address these matters by exploring how to identify key moments during the startup development in which the entrepreneurs could best benefit from mentorship. Also, considering the complexity involved, how can we measure mentorship outcomes?

Finally, the present study only partly explored the development and conduction of the mentorship process; due to length constraints and research strategy, a more comprehensive discussion of all related aspects of startup development was not possible. One major tool in the startup context, the Canvas, was left outside this initial debate and scope. Both the seminal business model canvas (Osterwalder \& Pigneur, 2010) and its most recent version, the lean canvas (Maurya, 2012), should be addressed by future research in ways to provide guidance for incubators, accelerators, mentors and mentees.

Unlike coaching, in which there are methodical processes and techniques, mentoring lacks systematization. Along with a statement in which one participant declared making use of experimentation to identify a best moment to propose mentoring, the need to improve the mentoring process naturally arose in different moments of the discussion, endorsing the necessity of considering lean mentorship proposal. Lean mentorship would provide to mentors a proper management tool to ascertain that they are providing the right knowledge, in adequate amount, at the necessary moment of the startup development.

\section{References}

Acs, Z. J., Audretsch, D. B., \& Lehmann, E. E. (2013). The knowledge spillover theory of entrepreneurship. Small Business Economics, 41(4), 757-774. http://dx.doi.org/10.1007/s11187-013-9505-9.

Agarwal, R., Audretsch, D., \& Sarkar, M. B. (2007). The process of creative construcction: knowledge spillovers, entrepreneurship, and economic growth. Strategic Entrepreneurship Journal, 1(3-4), 263-286. http://dx.doi.org/10.1002/sej.36.

Antoncic, B., \& Hisrich, R. D. (2003). Clarifying the intrapreneurship concept. Journal of Small Business and Enterprise Development, 10(1), 7-24. http://dx.doi.org/10.1108/14626000310461187.

Arrow, K. J. (1962a). Economic Welfare and the Allocation of Resources for Invention. In Rowley C.K. (Eds.), The rate and direction of inventive activity: economic and social factors (pp. 609-626).London: Palgrave. http://dx.doi.org/10.1515/9781400879762-024.

Arrow, K. J. (1962b). The economic implications of learning by doing. The Review of Economic Studies, 29(3), 155-173. http://dx.doi. org/10.2307/2295952.

Arruda, C., Nogueira, V., Cozzi, A., \& Costa, V. (2014). Causas da mortalidade de startups brasileiras. Núcleo de Inovação e Empreendedorismo, Fundação Dom Cabral.

Audretsch, D. B., \& Keilbach, M. (2008). Resolving the knowledge paradox : knowledge-spillover entrepreneurship and economic growth. Research Policy, 37(10), 1697-1705. http://dx.doi.org/10.1016/j.respol.2008.08.008.

Audretsch, D. B., \& Lehmann, E. E. (2005). Does the knowledge spillover theory of entrepreneurship hold for regions? Research Policy, 34(8), 1191-1202. http://dx.doi.org/10.1016/j.respol.2005.03.012.

Audretsch, D. B., \& Thurik, A. R. (2001). What's new about the new economy? Sources of growth in the managed and entrepreneurial economies. Industrial and Corporate Change, 10(1), 267-315. http://dx.doi.org/10.1093/icc/10.1.267.

Audretsch, D. B., Hülsbeck, M., \& Lehmann, E. E. (2012). Regional competitiveness, university spillovers, and entrepreneurial activity. Small Business Economics, 39(3), 587-601. http://dx.doi.org/10.1007/s11187-011-9332-9.

Audretsch, D. B., Keilbach, M. C., \& Lehmann, E. E. (2006). Entrepreneurship and economic growth. New York: Oxford University Press. http://dx.doi.org/10.1093/acprof:0so/9780195183511.001.0001.

Auerbach, C. F., \& Silverstein, L. B. (2003). Qualitative data: an introduction to coding and analysis (vol. 53). New York: New York University Press.

Bajwa, S. S., Wang, X., Nguyen Duc, A., \& Abrahamsson, P. (2017). "Failures" to be celebrated: an analysis of major pivots of software startups. Empirical Software Engineering, 22(5), 2373-2408. http://dx.doi.org/10.1007/s10664-016-9458-0.

Baluku, M. M., Leonsio, M., Bantu, E., \& Otto, K. (2019). The impact of autonomy on the relationship between mentoring and entrepreneurial intentions among youth in Germany, Kenya, and Uganda. International Journal of Entrepreneurial Behaviour \& Research, 25(2), 170-192. http://dx.doi.org/10.1108/1JEBR-10-2017-0373.

Blank, S. G. (2013). Why the lean start up changes everything. Harvard Business Review, 91(5), 64.

Bloor, M., Frankland, J., Thomas, M., \& Robson, K. (2001). Focus groups in social research. London: Sage. http://dx.doi. org/10.4135/9781849209175. 
Brashear-Alejandro, T., Barksdale, H., Bellenger, D. N., Boles, J. S., \& James, C. (2019). Mentoring characteristics and functions: mentoring's influence on salespeople. Journal of Business and Industrial Marketing, 34(2), 303-316. http://dx.doi.org/10.1108/JBIM-09-2017-0223.

Caten, C. S., Silva, D. S., Aguiar, R. B., Silva Filho, L. C. P., \& Huerta, J. M. P. (2019). Reshaping engineering learning to promote innovative entrepreneurial behavior. Brazilian Journal of Operations \& Production Management, 16(1), 141-148. http://dx.doi. org/10.14488/BJOPM.2019.v16.n1.a13.

Cholakova, M., \& Clarysse, B. (2015). Does the possibility to make equity investments in crowdfunding projects crowd out reward-based investments? Entrepreneurship Theory and Practice, 39(1), 145-172. http://dx.doi.org/10.1111/etap.12139.

Clarysse, B., \& Bruneel, J. (2007). Nurturing and growing innovative start-ups: the role of policy as integrator. $R$ \& D Management, 37(2), 139-149. http://dx.doi.org/10.1111/j.1467-9310.2007.00463.x.

Cooper, S. Y., \& Park, J. S. (2008). The impact of "incubator" organizations on opportunity recognition and technology innovation in new, entrepreneurial high-technology ventures. International Small Business Journal, 26(1), 27-56. http://dx.doi.org/10.1177/0266242607084658.

De Cock, R., Bruneel, J., \& Bobelyn, A. (2019). Making the lean start-up method work: the role of prior market knowledge. Journal of Small Business Management, 1-21. In press. http://dx.doi.org/10.1111/jsbm.12506.

Díez-Vial, 1., \& Fernández-Olmos, M. (2016). The effect of science and technology parks on a firm's performance: a dynamic approach over time. Technology Analysis and Strategic Management, 29(10), 1-14.

Eisenmann, T., Ries, E., \& Dillard, S. (2011). Hypothesis-driven entrepreneurship: the lean startup. (Harvard Business School Background, Note 812-095). Retrieved in 2019, July 09, from https://www.hbs.edu/faculty/Pages/item.aspx?num=41302

El Hallam, H., \& St-Jean, É. (2016). Nurturing entrepreneurial learning through mentoring. Journal of Developmental Entrepreneurship, 21(02), 1-18. http://dx.doi.org/10.1142/S1084946716500126.

Endeavor. (2015). Índice de cidades empreendedoras. Endeavor Brasil. Retrieved in 2019, July 09, from http://info.endeavor.org.br/ice2015

Ensher, E., Murphy, S., \& Vance, C. (2000). Mentoring and self-management career strategies for entrepreneurs. International Journal of Entrepreneurship and Innovation, 1(2), 99-108. http://dx.doi.org/10.5367/000000000101298595.

Euchner, J. (2016). Business model innovation. Research Technology Management, 59(3), 10-11. http://dx.doi.org/10.1080/0895630 8.2016.1161396.

Frederiksen, D. L., \& Brem, A. (2017). How do entrepreneurs think they create value? A scientific reflection of Eric Ries' Lean Startup approach. The International Entrepreneurship and Management Journal, 13(1), 169-189. http://dx.doi.org/10.1007/s11365-016-0411-x.

Ganguly, A., \& Euchner, J. (2018). Conducting business experiments. Research Technology Management, 61(2), 27-36. http://dx.doi. org/10.1080/08956308.2018.1421381.

Gartner, W. B., Starr, J. A., \& Bhat, S. (1998). Predicting new venture survival: an analysis of 'anatomy of a start-up' cases from Inc. Magazine. Journal of Business Venturing, 14(2), 215-232. http://dx.doi.org/10.1016/S0883-9026(97)00063-3.

Gurdon, M. A., \& Samsom, K. J. (2010). A longitudinal study of success and failure among scientist-started ventures. Technovation, 30(3), 207-214. http://dx.doi.org/10.1016/j.technovation.2009.10.004.

Hansford, B., Tennent, L., \& Ehrich, L. C. (2002). Business mentoring: help or hindrance? Mentoring \& Tutoring, 10(2), 101-115. http:// dx.doi.org/10.1080/1361126022000002428.

Hu, Q., Mason, R., Williams, S. J., \& Found, P. (2015). Lean implementation within SMEs: a literature review. Journal of Manufacturing Technology Management, 26(7), 980-1012. http://dx.doi.org/10.1108/JMTM-02-2014-0013.

International Association of Science Parks and Innovation. (2017). Definitions - IASP. Retrieved in 2019, July 09, from https://www. iasp.ws/Our-industry/Definitions

International Coach Federation. (2018). ICF definition of coaching. Lexington: ICF.

Klofsten, M., \& Öberg, S. (2012). Coaching versus mentoring: are there any differences? In A. Groen, R. Oakey, P. Van Der Sijde \& G. Cook (Eds.), New technology-based firms in the new millennium (New Technology Based Firms in the New Millennium, vol. 9, pp. 39-47), Bingley: Emerald Group Publishing Limited. https://doi.org/10.1108/S1876-0228(2012)0000009006.

Kram, K. E., \& lsabella, L. A. (1985). Mentoring alternatives: the role of peer relationships in career development. Academy of Management Journal, 28(1), 110-132.

Krueger, R. A., \& Casey, M. A. (2014). Focus groups: a practical guide for applied research (5th ed.). Los Angeles: Sage Publications.

Kurtulmuş, B. E., \& Warner, B. (2015). Entrepreneurial orientation and perceived financial performance - Does environment always moderate EO performance relation. Procedia: Social and Behavioral Sciences, 207, 739-748. http://dx.doi.org/10.1016/j.sbspro.2015.10.151.

Lean Enterprise Institute. (2019). What is lean? Retrieved in 2019, July 09, from https://www.lean.org/WhatsLean/

Lenarduzzi, V., Taibi, D., \& Link, S. (2016, Aug-Sept 31-02). MVP explained: a systematic mapping study on the definitions of minimal viable product. In 42nd Euromicro Conference on Software Engineering and Advanced Applications (SEAA) (pp. 112-119). Limassol: IEEE. http://dx.doi.org/10.1109/SEAA.2016.56.

Lester, S. W., Meglino, B. M., \& Korsgaard, M. A. (2008). The role of other orientation in organizational citizenship behavior. Journal of Organizational Behavior, 29(6), 829-841. http://dx.doi.org/10.1002/job.504.

Löfsten, H., \& Lindelöf, P. (2001). Science parks in Sweden - industrial renewal and development? R \& D Management, 31(3), 309-322. http://dx.doi.org/10.1111/1467-9310.00219.

Löfsten, H., \& Lindelöf, P. (2005). R\&D networks and product innovation patterns - Academic and non-academic new technology-based firms on Science Parks. Technovation, 25(9), 1025-1037. http://dx.doi.org/10.1016/j.technovation.2004.02.007.

Mansoori, Y., Karlsson, T., \& Lundqvist, M. (2019). The influence of the lean startup methodology on entrepreneur-coach relationships in the context of a startup accelerator. Technovation, 84-85(February), 1-11. http://dx.doi.org/10.1016/j.technovation.2019.03.001.

Maurya, A. (2012). Running lean (2nd ed.). Sebastopol: 0'Reilly Media.

Merriam, S. B., \& Tisdell, E. J. (2009). Qualitative research: a guide do design and implementation (4th ed.). San Francisco: Jossey-Bass Inc.

Mian, S. A. (1997). Assessing and managing the university technology business incubator: an integrative framework. Journal of Business Venturing, 12(4), 251-285. http://dx.doi.org/10.1016/S0883-9026(96)00063-8. 
Miles, M. B., \& Huberman, A. M. (1994). Qualitative data analysis: an expanded sourcebook (2nd ed.). Thousand Oaks: Sage Publications.

Mishra, D., Jain, S. K., \& Chaudhary, H. (2016). Analysing the feasibility of financial rewards for mentors engaged in entrepreneurial mentoring. International Journal of Evidence Based Coaching and Mentoring, 14(2), 135-218.

Monticelli, J. M., Bernardon, R., \& Trez, G. (2018). Family as an institution: the influence of institutional forces in transgenerational family businesses. International Journal of Entrepreneurial Behaviour and Research. In press. https://doi.org/10.1108/1JEBR-10-2017-0403

Moore, J. H., \& Wang, Z. (2017). Mentoring top leadership promotes organizational innovativeness through psychological safety and is moderated by cognitive adaptability. Frontiers in Psychology, 8, 1-10. http://dx.doi.org/10.3389/fpsyg.2017.00318.

Morrison, A., \& Bergin-Seers, S. (2002). Pro-growth small businesses: learning "architecture.”. Journal of Management Development, 21(5), 388-400. http://dx.doi.org/10.1108/02621710210426871.

Osterwalder, A., \& Pigneur, Y. (2010). Business model generation: a handbook for visionaries, game changers, and challengers. New Jersey: John Wiley \& Sons.

Power, B. (2014). How GE applies lean startup practices. Harvard Business Review, 13-15. Retrieved in 2019, July 09, from https://hbr. org/2014/04/how-ge-applies-lean-startup-practices/

Ratinho, T., \& Henriques, E. (2010). The role of science parks and business incubators in converging countries: Evidence from Portugal. Technovation, 30(4), 278-290. http://dx.doi.org/10.1016/j.technovation.2009.09.002.

Ries, E. (2008). The lean startup. Retrieved in 2019, July 09, from http://www.startuplessonslearned.com/2008/09/lean-startup.html

Ries, E. (2011). The lean startup. New York: Crown Business.

Ries, E. (2017). The startup way: how modern companies use entrepreneurial management to transform culture and drive long-term growth. New York: Currency.

Saunders, M., Lewis, P., \& Thornhill, A. (2016). Research methods for business students (7th ed., vol. 53). Cambridge: Cambridge University Press.

Schockett, M. R., \& Haring-Hidore, M. (1985). Factor analytic support for psychosocial and vocational mentoring functions. Psychological Reports, 57(2), 627-630. http://dx.doi.org/10.2466/pr0.1985.57.2.627.

Serviço de Apoio as Micros Empresas. (2014). Micro e pequenas empresas geram 27\% do PIB do Brasil. Brasilia: Sebrae.

Serviço de Apoio as Micros Empresas. (2015). Participação das micro e pequenas empresas na economia brasileira. Brasilia: Sebrae.

Silva, C. R. E. (2010). Orientação Profissional, mentoring, coaching e counseling: algumas singularidades e similaridades em práticas. Revista Brasileira de Orientação Profissional, 11(2), 299-309.

Squicciarini, M. (2009). Science parks, knowledge spillovers, and firms' innovative performance. Evidence from finland. (Economics Discussion Papers, No. 2009-32). Kiel Institute for the World Economy. Retrieved in 2019, July 09, from http://www.economicsejournal.org/economics/discussionpapers/2009-32

Stayton, J., \& Mangematin, V. (2018). Seed accelerators and the speed of new venture creation. The Journal of Technology Transfer, $44(4), 1-25$.

St-Jean, E. (2012). Mentoring as professional development for novice entrepreneurs: maximizing the learning. International Journal of Training and Development, 16(3), 200-216. http://dx.doi.org/10.1111/j.1468-2419.2012.00404.x.

St-Jean, E., \& Audet, J. (2012). The role of mentoring in the learning development of the novice entrepreneur. The International Entrepreneurship and Management Journal, 8(1), 119-140. http://dx.doi.org/10.1007/s11365-009-0130-7.

St-Jean, E., \& Audet, J. (2013). The effect of mentor intervention style in novice entrepreneur mentoring relationships. Mentoring \& Tutoring, 21(1), 96-119. http://dx.doi.org/10.1080/13611267.2013.784061.

St-Jean, É., \& Mathieu, C. (2015). Developing attitudes toward an entrepreneurial career through mentoring. Journal of Career Development, 42(4), 325-338. http://dx.doi.org/10.1177/0894845314568190.

Strauss, A. C., \& Corbin, J. (2008). Basics of qualitative research: techniques and procedures for developing grounded theory (3rd ed.). Thousand Oaks: SAGE Publications Inc. https://doi.org/10.4135/9781452230153.

Szulanski, G. (1996). Exploring internal stickiness: impediments to the transfer of best practice within the firm. Strategic Management Journal, 17(S2), 27-43. http://dx.doi.org/10.1002/smj.4250171105.

Ting, S. X., Feng, L., \& Qin, W. (2017). The effect of entrepreneur mentoring and its determinants in the Chinese context. Management Decision, 55(7), 1410-1425. http://dx.doi.org/10.1108/MD-07-2016-0477.

Waters, L., McCabe, M., Kiellerup, D., \& Kiellerup, S. (2002). The role of formal mentoring on business success and self-esteem in participantes of a new start-up program. Journal of Business and Psychology, 17(1), 107-121. http://dx.doi.org/10.1023/A:1016252301072.

Weinberg, F. J. (2019). How and when is role modeling effective? The influence of mentee professional identity on mentoring dynamics and personal learning outcomes. Group \& Organization Management, 44(2), 425-477. http://dx.doi.org/10.1177/1059601119838689.

Wu, X., Lyu, Y., Kwan, H. K., \& Zhai, H. (2019). The impact of mentoring quality on protégés' organization-based self-esteem and proactive behavior: the moderating role of traditionality. Human Resource Management, 58(4), 417-430. http://dx.doi.org/10.1002/hrm.21968.

Yang, X., Sun, S. L., \& Zhao, X. (2019). Search and execution: examining the entrepreneurial cognitions behind the lean startup model. Small Business Economics, 52(3), 667-679. http://dx.doi.org/10.1007/s11187-017-9978-z.

Yin, R. K. (2011). Qualitative research: from start to finish. New York: The Guilford Press. 


\section{Appendix A. Semi-structured questionnaire.}

1) How does entrepreneurial mentoring contribute to entrepreneurship? And to the entrepreneur?

2) Can we consider mentorship as a learning resource for technical and interpersonal skills?

3) What are the mentorship's advantages to entrepreneurs? And to others agents in the entrepreneurial and innovation ecosystem? (e.g., science and technology parks, accelerators, incubators)

4) What are the mentorship's disadvantages to entrepreneurs? And to others agents in the entrepreneurial and innovation ecosystem?

5) Do you think young entrepreneurs are able to absorb all the information needed to guarantee the ventures' success?

6) Is it possible to improve the mentoring process based on this new turbulent and dynamic context? How?

7) Do you think knowledge transfer provided by mentorship is key to success/sustainability more than experience itself?

8) How can knowledge produced within Universities, R\&D departments, and other sources, influence entrepreneurial action?

9) How does knowledge produced within Universities, R\&D departments, and other sources, contribute to innovation process in the ecosystem? 